\title{
The Mental Emotional Disorder Pattern: Study of National Basic Health Research 2007, 2013, and 2018
}

\author{
Sri Idaiani $^{1^{*}}$, Raharni $^{1}$, Siti Isfandari ${ }^{2}$ \\ ${ }^{1}$ Center for Research and Development of Health Resources and Services, Ministry of Health of Republic of Indonesia. \\ Jalan Percetakan Negara No.29 Jakarta, 10560, Indonesia \\ ${ }^{2}$ Center for Research and Development of Humaniora and Health Management, Ministry of Health of Republic of \\ Indonesia. Jalan Percetakan Negara No.29 Jakarta, 10560, Indonesia \\ "Corresponding Author. Email: sriidaiani@litbang.depkes.go.id
}

\begin{abstract}
Riset kesehatan dasar (Riskesdas) in 2007, 2013 and 2018 showed the prevalence of mental emotional disorder were $11.6 \%, 6.0 \%$ and $9.8 \%$ respectively. This study aims to describe mental emotional pattern among Indonesian and to compare the symptoms based on three Riskesdas. Riskesdas was a population survey. Inclusion criteria were people $\geq 15$ years old and able to answer questions. Self-reporting questionnaire (SRQ) consisted of 20 questions was used to assess mental emotional disorder. Subject was indicated mental emotional disorder if they have "yes" answer minimum in 6 questions. A statistical program SPSS 22.0 was used to analyze data. STATA map version 14.00 to visualize the prevalence among provinces was applied. Headache, sleep disturbance, poor appetite, and easily tired were the most frequent symptoms appeared in general population. While thinking of ending life, not feeling life is useful, feeling worthless, loss of interest in life, daily work is suffering were the most frequent symptoms in people with mental emotional disorder. Even though there were different prevalence of mental emotional disorder between 2007, 2013 and 2018 but the pattern of most symptoms both in general population and people with mental emotional disorder are similar. Keywords: mental emotional disorder, symptoms, Riskesdas
\end{abstract}

\section{INTRODUCTION}

Basic health research or riset kesehatan dasar (Riskesdas) is carried out by National Institute of Health Research and Development (NIHRD) of the Ministry of Health regularly every five year. Riskesdas 2007, 2013 and 2018 assessed mental emotional disorder (MED) in Indonesian population and the prevalence were $11.6 \%, 6.0 \%$ and $9.8 \%$ respectively [1-3]. Mental emotional disorder was a sign that someone was undergoing psychological changes which can heal itself, but can become a certain mental disorder if not solved.

Although there were different prevalence of MED from Riskedas to Riskesdas, but the symptoms has the same pattern. This already explained in previous publications [4,5]. Examining the patterns of MED symptoms in Indonesian population is interesting because it can reveal symptoms most commonly experienced by Indonesian general population or in populations with MED indication. Riskesdas 2007 and 2013 showed the most common symptoms experienced by general population were headache, sleep disturbance and no appetite, but populations who experience MED, have symptoms mostly thought ending life in mind, unable to play an useful part in life, feel as worthless person, loss of interest in things, daily work is suffering [4,5].

How about MED in the Indonesian population according to Riskesdas 2018? Does it have the same pattern of symptoms? Comparing results of these three national health surveys will be more interesting by displaying the results together with interesting visualizations to show comprehensive conclusions.

This analysis aims to describe mental emotional pattern among Indonesian and to compare the symptoms based on three Riskesdas (2007, 2013 and 2018).

\section{METHOD}

Riskesdas was a population survey assessing health indicators. In general, the sampling method of three Riskesdas were multi stage sampling. Completed information of these sampling were available in report book [1-3]. The inclusion criteria of people interviewed mental health questionnaire were $\geq 15$ years old and able to answer questions. Total samples were $657,795,703,946$, and 706,688 people respectively in 2007,2013 and 2018 . The self-reporting questionnaire (SRQ) consisted of 20 items questions; with "yes" or "no" answer was used to assess mental health condition [6]. Subject was indicated MED if they have "yes" answer minimum in 6 items. Each item or question represented of a psychological symptom. The items then were ranked from the most to the less, but only 5 highest rank is shown due to the two previous studies took 5 highest rank as well.

Univariate and descriptive analysis were implemented for this study using statistical program SPSS 22.0 with complex samples method in data analyzing. We used the STATA map version 14.00 to visualize the prevalence among provinces. All Riskesdas obtained ethical approval from Ethic 
Comission of NIHRD of Ministry of Health.

\section{RESULTS AND DISCUSSION}

The prevalence shows inconsistent pattern of $11,6 \%, 6,0 \%$ and $9,8 \%$. Figure 1 shows it below.

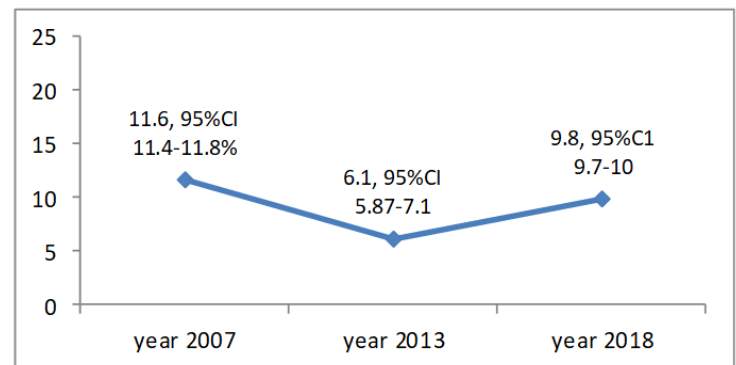

Figure 1. Mental Emotional Disorder Prevalence in 2007, 2013 and 2018

In 2013, the prevalence of MED decreased and then slightly increased in 2018. The STATA map categorized the prevalence of MED in color gradation automatically based on the maximum and minimum prevalence number in each map. The difference in prevalence between .provinces is illustrated in the following figure, while the provincial prevalence was provided in Riskesdas report books.[1-3]

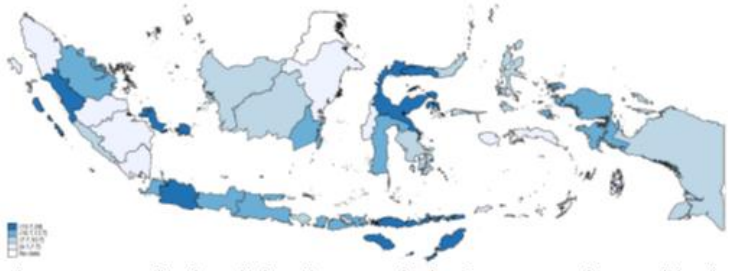

Figure 2. Map of Indonesia based on magnitude of MED prevalence, Riskesdas 2007

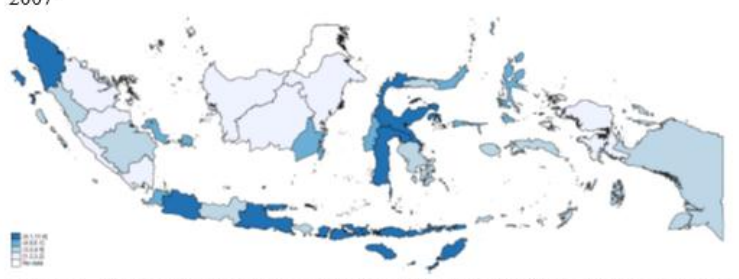

Figure 3. Map of Indonesia based on magnitude of MED prevalence, Riskesdas 2013

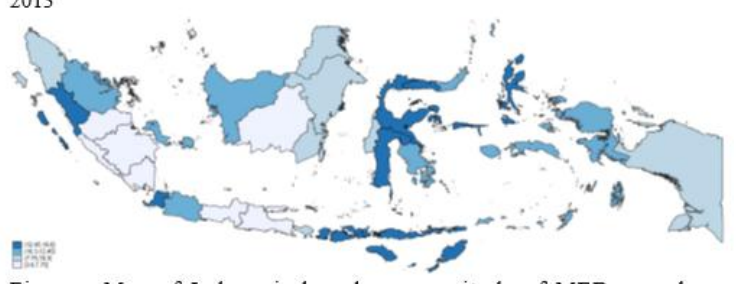

Figure Map of Indonesia based on magnitude of MED prevalence Riskesdas 2018

Based on picture above, shows East Nusa Tenggara and Central Sulawesi are consistent having high prevalence of MED compared to other provinces in three periods.

Twenty questions of SRQ-20, reflecting anxiety and depression and somatic symptoms. The description of symptoms in general population and MED people was described in two tables below.
Table 1. The five highest symptoms in the Indonesian population.

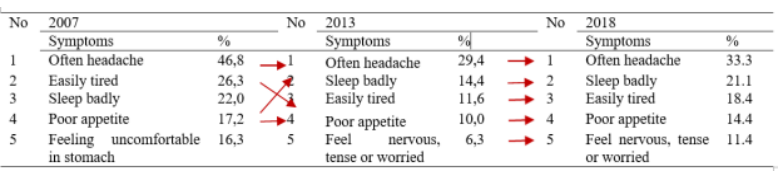

It shows that 4 out of 5 most symptoms experienced by general population are the same in 2007 and 2013. Headache was the highest position, easily tired and sleep badly (disturbance) in second or third ranking, while poor appetite always ranks fourth. However, the number (percentage) obtained was different and it was to be lower in 2013.There is similar pattern between 2013 and 2018. Next table shows the most common symptoms of people with MED (those having more than 6 yes answer)

Table 2. The five highest common symptoms of people with MED.

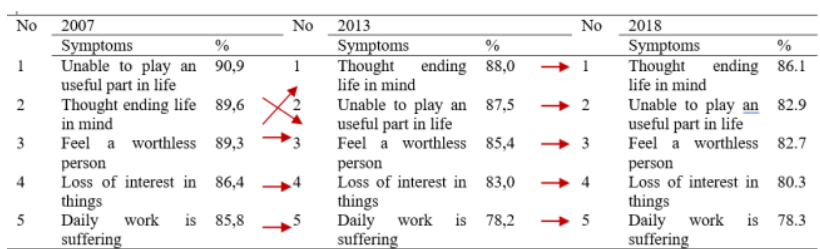

Table 2 shows that pattern of symptoms in MED people is same. They are thought ending life in mind, unable to play a useful part in life, feel worthless person, loss of interest in things, daily work is suffering. The ranks of symptoms in 2013 and 2018 are absolutely same.

This analysis didn't assess relationship between prevalence and characteristics. The relationship between population characteristics and MED prevalence based on Riskesdas 2007 and 2013 was available in the previous article.[4,5] Inconsistent pattern of prevalence is probably due to MED assessment which is only for conditions in the past month that allow symptoms to come and go. However, the decline pattern is similar with that in cohort study of non-communicable diseases in Bogor City. [7] In that city, MED prevalence in 2011 was $29,0 \%$, in 2012 was $33,9 \%$ and in 2013 was $23,2 \%$.

The provinces identified always have a high prevalence of MED, are West Nusa Tenggara, East Nusa Tenggara, South Sulawesi and Central Sulawesi. STATA map automatically classifies regions based on the high and low prevalence in the same year, but not with the same category restrictions for different years. However, it can be said that provinces that consistently have high prevalence need to explore the causes or things that are influence it.

There is different pattern of symptoms experienced by the general population and population with MED. The general population experience more somatic symptoms such as headaches, fatigue, sleep badly, poor appetite, abdominal 
people who experience MED are generally dominated by depressive symptoms. We suggest a further observation for people with depression symptoms because most likely they are experiencing MED therefore it can be managed or treated earlier by preventing stress and mental disorders. In the provinces of West Nusa Tenggara, East Nusa Tenggara, Central Sulawesi, South Sulawesi, which always have a high prevalence, promotion and prevention programs are needed therefore MED does not continue to a mental disorder.

\section{ACKNOWLEDGMENT}

The authors would like to thank to Head of Health Services Division for facilitating data proposed. A big thank was also for Head of Data Management of National Institute of Health Research and Development for providing data quickly.

\section{REFERENCES}

[1] NIHRD (National Institute of Health Research and Development) Ministry of Health of Republic of Indonesia. Basic Health Research Report 2007. Jakarta;

[2] NIHRD (National Institute of Health Research and Development) Ministry of Health of Republic of Indonesia. Basic Health Research Report 2013. Jakarta; 2013.

[3] NIHRD (National Institute of Health Research and Development) Ministry of Health of Republic of Indonesia. Basic Health Research Report 2018. Jakarta;

[4] Idaiani S, Suhardi, Kristanto AY. Mental Emosional MKI.pdf. Maj Kedokt Indon. 2009;59(10):473-9.

[5] Idaiani S, Priharini S, Yunita I, Lely Indrawati. Mental emotional disorder pattern of Indonesian population: a study of national basic health research 2007 and 2013 . 2014;

[6] (WHO) WHO. A user's guide to the self reporting questionnaire (SRQ). Geneva; 1994.

[7] Idaiani S, Nur Sapardin A, Sulistiowati, Eva. Gambaran Kohor 2011-2013 Gangguan Mental Emosional Berdasarkan SRQ-20 pada Penduduk Kelurahan Kebon Kalapa Bogor. Bul Penelit Kesehat. 2015;43(4):273-8.

[8] Ghubash MTAR, Daradkeh TK. Al Ain Community Psychiatric Survey. I . Prevalence and socio-demographic correlates. 2001;20-8.

[9] (WHO) WHO. Iraq Mental Health Survey 2006/7 Report. WHO, Geneva [Internet]. 2009; Available from:

http://scholar.google.es/scholar?hl=es\&q=Iraq+Mental+Hea 1 th + Survey $+2006 \% 2 F 7+$ Report\&btnG $=\& 1 r=\# 4$
This analysis results are consistent with previous Riskesdas results. Although it seems inconsistency of MED prevalence but the pattern of symptoms is the same. In general population is dominated by somatic symptoms while in 
[16] Soni A, Fahey N, Byatt N, Prabhakaran A, Simas TAM, Vankar J, et al. Association of common mental disorder symptoms with health and healthcare factors among women in rural western India: Results of a cross-sectional survey. BMJ Open. 2016;6(7):1-8.

[17] Tesfaye M, Hanlon C, Tessema F, Prince M, Alem A. Common mental disorder symptoms among patients with malaria attending primary care in Ethiopia: A cross-sectional survey. PLoS One. 2014;9(9).

[18] Alonso J, Benjet C. Socio-economic variations in the mental health treatment gap for people with anxiety, mood, and substance use disorders : results from the WHO World Mental Health ( WMH ) surveys. 2017;(Cidi).

[19] Institute of Public Health. Malaysia Ministry of Health. National Health and Morbidity Suvey. 2015.

[20] Pradeep BS, Gururaj G, Varghese M, Benegal V, Rao GN, Sukumar GM, et al. National mental health survey of India, 2016 - rationale, design and methods. PLoS One. 2018;13(10):1-21.

[14] Munetsi E, Simms V, Dzapasi L, Chapoterera G, Goba N, Gumunyu T, et al. Trained lay health workers reduce common mental disorder symptoms of adults with suicidal ideation in Zimbabwe: A cohort study. BMC Public Health. 2018;18(1):1-7.

[15] Koopmans PC, Bültmann U, Roelen CAM, Hoedeman R, Van Der Klink JJL, Groothoff JW. Recurrence of sickness absence due to common mental disorders. Int Arch Occup Environ Health. 2011;84(2):193-201. 